\section{An Evaluation of U.S. Tart and Sweet Cherry Producers Trait Prioritization: Evidence from Audience Surveys}

\author{
Chengyan Yue ${ }^{1,10}$ \\ Department of Horticultural Science and Department of Applied Economics, \\ University of Minnesota, Twin Cities, 1970 Folwell Avenue, St. Paul, MN \\ 55108 \\ R. Karina Gallardo ${ }^{2}$ \\ School of Economic Sciences, Puyallup Research and Extension Center, \\ Center for Precision Agriculture and Automated Systems, Washington State \\ University, 2606 W. Pioneer, Puyallup, WA 98371
}

James J. Luby ${ }^{3}$ and Alicia L. Rihn ${ }^{4}$

Department of Horticultural Science, University of Minnesota, Twin Cities, 1970 Folwell Avenue, St. Paul, MN 55108

James R. McFerson ${ }^{5}$

Washington Tree Fruit Research Commission, 1719 Springwater Avenue, Wenatchee, WA 98801

Vicki McCracken ${ }^{6}$

School of Economic Sciences, Washington State University, P.O. Box 646210, Hulbert Hall 101, Pullman, WA 99164

\section{Nnadozie Oraguzie ${ }^{7}$ \\ Department of Horticulture, Washington State University, Prosser, WA 99350}

Cholani Weebadde ${ }^{\mathbf{8}}$, Audrey Sebolt ${ }^{\mathbf{9}}$, and Amy Iezzoni ${ }^{\mathbf{3}}$

Department of Horticulture, Michigan State University, East Lansing, MI 48824-1325

Additional index words. fruit size, ordered probit model, productivity, stone fruit

\begin{abstract}
Developing new cherry cultivars requires breeders to be aware of existing and emerging needs throughout the supply chain, from producer to consumer. Because breeding programs in perennial crop plants like sweet and tart cherries require both extended time and extensive resources, understanding and targeting priority traits is critical to improve the efficiency of breeding programs. This study investigated the relative importance of fruit and tree traits to sweet and tart cherry producers using ordered probit models. Tart cherry producers considered productivity and fruit firmness to be the most important traits, whereas sweet cherry producers regarded fruit size, fruit flavor, fruit firmness, freedom from pitting, and powdery mildew resistance as important traits. The location of producers' orchards and their demographic backgrounds influenced their perceptions of the importance of traits. Our findings provide a quantitative basis to reinforce existing priorities of breeding programs or suggest new targets.
\end{abstract}

Received for publication 20 Feb. 2014. Accepted for publication 29 Apr. 2014.

${ }^{1}$ Associate Professor and Bachman Endowed Chair in Horticultural Marketing.

${ }^{2}$ Assistant Professor and Extension Specialist.

${ }^{3}$ Professor.

${ }^{4}$ Ph.D. Student.

${ }^{5}$ Manager.

${ }^{6}$ Professor and Associate Director.

${ }^{7}$ Associate Professor.

${ }^{8}$ Assistant Professor.

${ }^{9}$ Associate Scientist.

${ }^{10}$ To whom reprint requests should be addressed; e-mail yuechy@umn.edu.
Oregon (38,150 t), Michigan (15,100 t), and Montana (2,470 t) (USDA, 2011). In 2010, $97 \%$ of tart cherries were processed and were worth \$39.7 million (NASS, 2013). Michigan was the leading tart cherry-producing state (135.0 million pounds) followed by Utah (23.0 million pounds), Washington (15.4 million pounds), New York (7.8 million pounds), and Wisconsin (5.7 million pounds) (USDA, 2011). To meet growing domestic and international market demands, producers require development and commercialization of superior new cultivars.

New cherry cultivars with improved performance benefit producers directly. However, other members of the supply chain benefit from new cultivars with improved quality, availability, affordability, and health benefits. Cherry breeding programs face a significant challenge to develop cultivars incorporating the range of attributes preferred by the various components of the supply chain. All breeding programs require significant financial, human, and time resources to develop, evaluate, and commercialize new cultivars, but this is especially true for crops with long juvenility periods and extensive, complex field testing requirements such as cherries (Fuglie and Walker, 2001; Song et al., 2008). Cultivar development routinely takes more than 20 years from the initial cross to commercialization. Thus, any strategy that hastens this process and improves cherry breeding efficiency has high potential economic impact throughout the supply chain.

Genetic improvement in cherry has contributed significantly to improved product quality, management practices, and product uniformity (Hennessy et al., 2004; Lusk, 2007). Continued development of additional tools using genetic engineering technology can greatly improve breeding program efficiency, but application of this technology requires significant additional knowledge and resources. Therefore, focusing on priority traits is important (Alpuerto et al., 2009; Luby and Shaw, 2001). Supply chain members' decisions are often influenced by needs, tradition, personal experiences, preferences, and beliefs that can lead to discrepancies among member groups. For producers, different biotic and abiotic stresses related to geographic location, pest pressure, storage and handling infrastructure, etc., complicate breeding program targets (Sy et al., 1997; Tano et al., 2003). Thus, cherry breeding programs could enhance efficiency of resource use and commercial impact by improved understanding of factors underlying preferences of supply chain members.

Unfortunately, few systematic studies identifying priority traits are available for the various components of the cherry supply chain to provide guidance to breeding programs in establishing target trait priorities. Breeders may rely on their personal experiences and producers' feedback to prioritize plant and fruit traits, but this challenge is magnified when attempting to consider the possibly discrepant preferences of different members for the supply chain. The scant literature that exists typically does not focus 
on how the breeding program objectives were determined, but instead focuses on the objectives themselves. For instance, Stehr (2001) described a German cherry breeding program that focused on cracking resistance and tree health traits resulting from the high humidity of the region along with fruit size and firmness.

Producers' preferences are greatly affected by their different end markets and horticultural practices (Sy et al., 1997). Because the majority of tart cherries are processed (NASS, 2013) and harvested by machine, fruit bruising reduces product quality and can heighten pit removal problems; thus, fruit firmness is an important quality trait. (Timm and Guyer, 1998). Most sweet cherries are sold fresh (NASS, 2013). Therefore, traits important to end consumers (such as size, color, soluble solid concentration, $\mathrm{pH}$, sweet-sour balance, flavor, texture, and external firmness) are often targeted in sweet cherry breeding programs (Dever et al., 1996; Kappel et al., 1996). The needs of market intermediaries also differ significantly between tart and sweet cherry industries.

In addition to the end market's impact, regional biotic and abiotic stresses impact producers' value of traits (Tano et al., 2003). For cherries, a humid climate increases disease and pest pressure from brown rot (Monilinia) and cherry fruit flies (Tamm et al., 2002; Wearing et al., 2001). Consequently, as a result of different markets and regional stresses, identifying important cherry tree and fruit traits is challenging.

Currently in the United States, cherry breeders set goals based on industry feedback and regional perceived needs without the insight provided by a systematic study of supply chain members' prioritization of traits. As part of a larger strategic socioeconomic analysis of trait values across cherry supply chain members, this study focused on sweet and tart cherry producers' preferences for tree and fruit traits. This constitutes an important first step to fill a knowledge gap and improve the efficiency of breeding programs.

\section{Materials and Methods}

Pre-study producer interviews. To identify the fruit and tree attributes deemed important to tart and sweet cherry producers and the most decisive factors influencing cultivar adoption, we interviewed a small number of tart cherry producers in Michigan and sweet cherry producers in Washington before the development of the survey instrument. Producer interviews were conducted over the phone or in person. Specifically, producers were asked how they made decisions about which varieties to grow, the major use/market of their products (fresh, processed, etc.), where they obtained their plant material, what fruit traits were important, how they defined "good" and "bad" levels of those traits, what plant traits were important, what influenced their decision to adopt a new cultivar, and if they anticipate any barriers to adopting new cultivars. From pre-survey interview results, a condensed list of nine tree and fruit traits was developed as answer options in the formal audience survey. The traits included in the audience surveys were those that were mentioned by more than $60 \%$ of the interviewed producers. For tart cherry producers, four traits (i.e., free of blemish, size, pit shape, and nutriceutical/antioxidant) were not included in the final trait list. For sweet cherry, flesh color, fruit shape, phytonutrient content, stem attractiveness, and aroma were not included in the final trait list. A category "other" was included in the audience survey (detailed below) to capture these other traits.

Audience survey protocol. The survey was implemented using Turning Point ${ }^{\mathrm{TM}}$ audience polling software (Youngstown, OH). This software allows researchers to combine data collection with instantaneous communication of the results to participants. Specifically, audience participants submit responses using ResponseCard $^{\mathrm{TM}}$ keypads, hereafter referred to as "clickers." Each clicker allows a participant to submit one answer per question. After all participants submit their answers, the technology presents instant feedback, which is graphically displayed on a slide to the audience. Institutional Review Board approval for the study was obtained from the authors' universities.

Participants were given a clicker at the beginning of the presentation. Along with the clicker, each respondent was provided with a pencil and note card. The audience survey began with introduction slides describing the overall RosBREED project goal of increasing the efficiency of developing new breakthrough rosaceous fruit cultivars through the use of marker-assisted breeding technologies. The presenter then explained the tree and fruit traits to be used as answer options in the following survey. After the introductory slides, two slides with unrelated questions were presented to train participants on how to use the system. All questions were given in a multiple-choice format with 10 answer options. The note cards were used by the participants to write down specific other traits if they selected "other" traits. Note that a maximum of 10 fruit and tree traits were included in the audience surveys because the clicker technology allows a maximum of 10 response choices.

The first two questions of the actual survey inquired about the MOST and the SECOND MOST important fruit quality or tree trait for a successful tart or sweet cherry cultivar. The list of answer options was the same for all tart cherry questions and included: fruit color, fruit firmness, fruit uniformity, sweetness/soluble solids, pit removal, machine harvest ability, productivity, disease resistance, and other traits. The answer options for all sweet cherry survey questions included: fruit size, fruit skin color, fruit flavor, fruit firmness, freedom from pitting, extended harvest season, self-fertility, viral disease resistance, powdery mildew resistance, and other traits. Participants were given time to fill in their note cards with traits that they deemed as important but were not listed. The next two questions requested participants to indicate which trait (from the same traits listed in the previous questions) was the LEAST important and then the SECOND least important. The remainder of the survey consisted of questions addressing total acres of cherry orchards they owned/managed, their years involved in the decision-making process of the orchard, their 2010 gross farm income, and their role in the orchard (owner, lessee, manager, or other). On completion of the survey, participants were thanked for their time and the clickers, pencils, and note cards were collected.

Econometric model. Participants were only allowed to choose one answer per question (there were nine traits for the tart cherries and 10 traits for the sweet cherries). Hence, an ordered probit model was used to analyze producers' preferences and rankings for the tart cherry and sweet cherry tree and fruit traits. An ordered probit model is appropriate because survey participants' responses were discrete and ordered. Participants were asked to indicate the "most important," "second most important," "second least important," and "least important" traits. There were five levels of importance for the nine or 10 traits in the ordered probit model. That is, the data set included a ranking for each trait for each respondent, coded as follows: the value of 5 was assigned if the trait was the most important trait; 4 for the second most important trait; 2 for the second least important trait; and 1 for the least important trait. If a trait was not selected as the most important, second most important, second least important, or the least important trait, it was assigned the neutral value 3 .

Suppose $U_{i j}$ is the utility/satisfaction that producer $i$ derives from tart cherry/sweet cherry trait $j . \mathrm{U}_{\mathrm{ij}}$ can be expressed as follows for tart cherries:

$$
\begin{aligned}
U_{i j}= & \alpha_{0}+\alpha_{1} \text { Color }_{i}+\alpha_{2} \text { Firmness }_{i} \\
& +\alpha_{3} \text { Uniformity }_{i}+\alpha_{4} \text { Sweet }_{i} \\
& +\alpha_{5} \text { Pitremoval }_{i}+\alpha_{6} \text { Harvest }_{i} \\
& +\alpha_{7} \text { Productivity }_{i}+\alpha_{8} \text { Disease }_{i} \\
& +\alpha_{9} \text { Other }_{i}+\beta_{1} \text { yearsexp }_{i}+\beta_{2} \text { income }_{i} \\
& +\beta_{3} \text { role }_{i}+\beta_{4} \text { location }_{i}+\delta \text { socio } \\
& - \text { demographics }_{i}{\text { X } \text { trait }_{j}}+\varepsilon_{i j} ; \\
& i=1, \ldots, 55(n)(1)
\end{aligned}
$$

Similarly, for sweet cherries:

$$
\begin{aligned}
& U_{i j}=\alpha_{0}+\alpha_{1} \text { Size }_{i}+\alpha_{2} \text { Color }_{i}+\alpha_{3} \text { Flavor }_{i} \\
& +\alpha_{4} \text { Firmness }_{i}+\alpha_{5} \text { Freepitting }_{i} \\
& +\alpha_{6} \text { ExtHarvest }_{i}+\alpha_{7} \text { Fertility }_{i} \\
& +\alpha_{8} \text { Viralresist }_{i}+\alpha_{9} \text { Mildewresist }_{i} \\
& +\alpha_{10} \text { Other }_{i}+\beta_{1} \text { yearsexp }_{i} \\
& +\beta_{2} \text { income }_{i}+\beta_{3} \text { role }_{i}+\beta_{4} \text { location }_{i}
\end{aligned}
$$

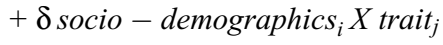

$$
\begin{aligned}
& +\varepsilon_{i j} ; i=1, \ldots, 87(n)(1)
\end{aligned}
$$

For each equation, $\alpha$ is a vector of the coefficients associated with the fruit/tree traits; $\beta$ is a vector of coefficients associated with the producer's sociodemographics; $\delta$ is 
a row vector of the coefficients associated with the interaction effects between fruit/tree traits and producers' demographic characteristics. $\varepsilon_{i j}$ is the residual error term that is not captured by the explanatory variables and is assumed to follow a normal distribution with mean zero and SD $\sigma_{\varepsilon}$. The interaction effect variables are standardized with mean zero and SD of one. There are 55 tart cherry producers and $87(n)$ sweet cherry producers, and for each producer, there are nine and 10 $(J)$ fruit/tree traits, respectively. Here indicator variables are used as regressors to identify traits. One category of traits must be excluded during estimation to avoid perfect multicollinearity (Greene and Hensher, 2008). For the sweet cherries, disease resistance was excluded. For the tart cherries, viral disease resistance was excluded. The estimated coefficients of the other variables are all interpreted relative to the excluded (base) variable. Consequently, it does not matter which variable is the base variable in the model. The magnitude of the coefficients depends on the excluded category, but their interpretation is only meaningful relative to the excluded trait and hence all interpretations and conclusions are the same.

The model was estimated using a STATA software package. To predict the probability that a trait would be ranked in each category (most important, second most important, neutral, second least important, and least important), we estimated the marginal values of the variables. Once again, for tart cherries, disease resistance was used as a base for comparison and viral disease resistance was used as a base for comparison for sweet cherries. The marginal values were also calculated for the interaction effect (i.e., traits $\times$ sociodemographic variables) but only the statistically significant marginal values are presented and discussed. Marginal values were calculated after the interaction effects were standardized.

Similar to the coefficient interpretation, the ordered probit model significance tests indicate the significance for traits compared with the excluded trait, disease resistance for tart cherries and viral disease resistance for sweet cherries. To determine if the remaining traits were rated significantly different from all other traits, pairwise $t$ tests were conducted between the coefficients of the traits from the ordered probit model.

\section{Results}

The audience surveys were conducted at the Washington State Horticultural Association meetings with 107 sweet cherry producers and the Great Lakes Expo in Michigan where 61 tart cherry producers were surveyed. Of the 107 sweet cherry producer participants, 20 (19\%) were incomplete and unusable resulting in 87 surveys being used in the analysis. Regarding tart cherry producers' responses, six (9.8\%) were incomplete and unusable resulting in 55 tart cherry producer participants' responses being used in the analysis. Consequently, a total of 168 cherry producers participated in the surveys but only 142 were used in the analyses.

On the basis of the sample data, tart cherry growers on average owned or managed 55 to 99 acres of tart cherry orchards, which is close to Michigan state average acreage 53.6 acres (Census of Agriculture, 2007), and had 16 to 20 years of experience in decisionmaking for the orchards (Table 1). Sweet cherry growers owned or managed 15 to 24 acres, which is close to Washington state average of 17.9 acres (Census of Agriculture, 2007), and had 6 to 15 years of experience. Approximately $82 \%$ of the tart cherry participants were owners followed by $13 \%$ managers and $4 \%$ lessees. Approximately $48 \%$ of sweet cherry participants were owners, $37 \%$ were managers, and nearly $15 \%$ were lessees. All tart cherry participants were from Michigan, whereas all sweet cherry participants were from Washington. In 2010, gross farm income averaged $\$ 75,000$ to $\$ 99,999$ for tart cherries and $\$ 100,000$ to $\$ 249,999$ for sweet cherries.

Tart cherries. Table 2 shows the estimated coefficients for the importance of tart cherry traits based on producers' preferences. The disease resistance trait was used as the base for estimation. Estimated coefficients indicate that producers placed higher importance on productivity followed by fruit firmness when compared with disease resistance, all else constant in the model. Producers placed lower importance on fruit color followed by pit removal, fruit uniformity, and soluble solids when compared with disease resistance. Other traits and machine harvest ability are not significantly different from disease resistance with $P$ values of 0.38 and 0.16 , respectively.

The interaction effect between disease resistance and years of experience is significant and positive indicating that disease resistance is more important to producers who have more experience growing tart cherries (Table 2). The positive interaction effect between pit removal and acreage is marginally significant $(P=0.10)$ indicating that the ease of pit removal becomes more important as the size of the orchard increases.

Estimates of marginal effects indicate pit removal, productivity, and fruit firmness have significantly higher probabilities of being chosen as the most important trait when compared with disease resistance (Table 3). Conversely, soluble solids content followed by fruit uniformity, fruit color, and machine harvest ability have significantly lower probabilities of being chosen as the most important trait compared with disease resistance. "Other traits" is not significantly different from disease resistance. Regarding the marginal effects of the interaction terms, producers with more years of experience have a significantly higher probability of choosing disease resistance as the most important trait when compared with producers with less years of experience.

The ordered probit model results show that productivity and fruit firmness are the most important traits for tart cherry producers

Table 1. Summary statistics for cherry producer demographic variables used in an ordered probit model for producer audience survey participants at two producer meetings in 2011 .

\begin{tabular}{|c|c|c|c|c|c|}
\hline \multirow[b]{2}{*}{ Variable } & \multirow[b]{2}{*}{ Description } & \multicolumn{2}{|c|}{ Tart cherry $(\mathrm{n}=55)$} & \multicolumn{2}{|c|}{ Sweet cherry $(n=87)$} \\
\hline & & Mean & $\mathrm{DF}$ & Mean & $\mathrm{DF}$ \\
\hline Acres & $\begin{array}{l}\text { Total number of orchard acres owned } \\
\quad \text { or managed } \\
\begin{array}{l}1=<5 \text { acres } \\
2=5 \text { to } 14 \text { acres } \\
3=15 \text { to } 24 \text { acres } \\
4=25 \text { to } 49 \text { acres } \\
5=50 \text { to } 99 \text { acres } \\
6=100 \text { to } 249 \text { acres } \\
7=250 \text { to } 499 \text { acres } \\
8=500 \text { to } 1000 \text { acres } \\
9=>1000 \text { acres }\end{array}\end{array}$ & 5.40 & 1.77 & 3.71 & 2.32 \\
\hline Years & $\begin{array}{l}\text { Participant's years of decision-making } \\
\quad \text { experience } \\
\begin{array}{l}1=1 \text { to } 5 \text { years } \\
2=6 \text { to } 10 \text { years } \\
3=11 \text { to } 15 \text { years } \\
4=16 \text { to } 20 \text { years } \\
5=>20 \text { years }\end{array}\end{array}$ & 4.00 & 0.79 & 2.72 & 1.63 \\
\hline Income & $\begin{array}{l}2010 \text { gross farm income } \\
1=<\$ 25,000 \\
2=\$ 25,000 \text { to } \$ 49,999 \\
3=\$ 50,000 \text { to } \$ 74,999 \\
4=\$ 75,000 \text { to } \$ 99,999 \\
5=\$ 100,000 \text { to } \$ 249,999 \\
6=\$ 250,000 \text { to } \$ 499,999 \\
7=\$ 500,000 \text { to } \$ 999,999 \\
8=\$ 1,000,000 \text { to } \$ 2,499,999 \\
9=>\$ 2,500,000\end{array}$ & 4.45 & 2.31 & 5.41 & 2.53 \\
\hline Location & $\begin{array}{l}\text { Role of participant } \\
1=\text { owner } \\
2=\text { lessee } \\
3=\text { manager } \\
\text { Location of orchards }\end{array}$ & $\begin{array}{c}1.31 \\
82.69 \% \\
3.85 \% \\
13.4 \% \\
\text { Michigan } 100 \%\end{array}$ & 0.70 & $\begin{array}{c}1.17 \\
48.15 \% \\
14.81 \% \\
37.04 \% \\
\text { Washington } 100 \%\end{array}$ & 1.16 \\
\hline
\end{tabular}


(Table 2). However, the $t$ test results show productivity and fruit firmness are not significantly different from each other indicating the traits have a similar level of importance (Table 4). Productivity and fruit firmness are significantly different from all of the other traits. The coefficient for "other traits" is not significantly different from machine harvest ability; however, other is significantly differmity, and soluble solids. Machine harvest ability is significantly different from fruit color, pit removal, fruit uniformity, and soluble solids. Fruit color, pit removal, fruit uniformity, and soluble solids are not significantly different from one another. ent from fruit color, pit removal, fruit unifor-

Table 2. Estimated ordered probit model coefficients indicating the relative importance of tart cherry fruit quality and plant traits to cherry producers based on audience survey data collected at a producer meeting in $2011(\mathrm{n}=55)$.

\begin{tabular}{|c|c|c|c|}
\hline Variable & Coefficient $^{\mathrm{z}}$ & SE & $P$ value \\
\hline Fruit color & $-0.912 * * *$ & 0.236 & 0.000 \\
\hline Fruit firmness & $0.643 * * *$ & 0.234 & 0.006 \\
\hline Fruit uniformity & $-0.985 * * *$ & 0.238 & 0.000 \\
\hline Soluble solids & $-1.145 * * *$ & 0.238 & 0.000 \\
\hline Pit removal & $-0.941 * * *$ & 0.256 & 0.000 \\
\hline Machine harvest ability & -0.332 & 0.235 & 0.159 \\
\hline Productivity & $0.774 * * *$ & 0.232 & 0.001 \\
\hline Other & -0.215 & 0.242 & 0.375 \\
\hline Disease resistance & Base & Base & Base \\
\hline Disease resistance $*$ years of experience $e^{\mathrm{y}, \mathrm{x}}$ & $0.158 * *$ & 0.066 & 0.017 \\
\hline Pit removal $*$ acreage $^{\mathrm{w}}$ & 0.107 & 0.065 & 0.101 \\
\hline Cutoff value $1^{\mathrm{v}}$ & -1.925 & 0.179 & \\
\hline Cutoff value $2^{\mathrm{v}}$ & -1.403 & 0.167 & \\
\hline Cutoff value $3^{v}$ & 0.841 & 0.155 & \\
\hline Cutoff value $4^{\mathrm{v}}$ & 0.107 & 0.065 & \\
\hline Number of observations & 480 & & \\
\hline Log likelihood & -483.026 & & \\
\hline Pseudo $R^{2}$ & 0.127 & & \\
\hline
\end{tabular}

z*, **,*** Significant at $P \leq 0.100,0.050$, or 0.010 , respectively.

y Only significant sociodemographic and interaction terms are represented. The acreage used in the estimation is the midpoint of each acreage category. The years of experience used in the estimation is the midpoint of each years of experience category.

Interaction between fruit trait and years of decision-making experience. The interaction is standardized with mean zero and SD of one.

winteraction between fruit trait and size (in acres) of orchard. The interaction is standardized with mean zero and SD of one.

${ }^{\mathrm{v}}$ Cutoff value for the ordered probit model.
Sweet cherries. Table 5 shows the estimated coefficients for the importance of sweet cherry traits to producers. Viral disease resistance trait was used as the base for estimation. The estimated coefficients indicate that producers place higher importance on fruit size followed by fruit flavor, fruit firmness, other, freedom from pitting, and powdery mildew resistance when compared with viral disease resistance. Fruit skin color, self-fertility, and extended harvest season are not significantly different from viral disease resistance with $P$ values of $0.50,0.93$, and 0.50 , respectively.

The negative interaction effect between fruit flavor and acreage is significant indicating that fruit flavor becomes less important as the orchard size increases (Table 5). The negative interaction effect for extended harvest season and years of experience is marginally significant $(P=0.11)$ indicating that the extended harvest season trait becomes less important as the producer gains more experience.

For sweet cherries, estimates of the marginal effects indicate fruit size, fruit firmness, other, and freedom from pitting have significantly higher probabilities of being selected as the most important trait when compared with viral disease resistance (Table 6). Fruit flavor has a significantly lower probability of being selected as the most important trait when compared with viral disease resistance. Fruit skin color, extended harvest season, self-fertility, and powdery mildew resistance are not significantly different from viral disease resistance. Participants with larger orchards (by number of acres) have a lower probability of selecting fruit flavor as the

Table 3. Estimated marginal effect of relative importance of tart cherry traits based on audience survey data collected at tart cherry producer meetings in $2011(\mathrm{n}=$ $55)$.

\begin{tabular}{|c|c|c|c|c|c|}
\hline & $\begin{array}{l}\text { Least important } \\
\text { trait }(\text { ranking }=1) \\
\text { dy/dx }\end{array}$ & $\begin{array}{l}\text { Second least important } \\
\text { trait }(\text { ranking }=2) \\
\text { dy/dx }\end{array}$ & $\begin{array}{c}\text { Not selected } \\
(\text { ranking }=3) \\
\text { dy } / \mathrm{dx}\end{array}$ & $\begin{array}{l}\text { Second most important } \\
\text { trait (ranking }=4) \\
\text { dy } / \mathrm{dx}\end{array}$ & $\begin{array}{l}\text { Most important trait } \\
(\text { ranking }=5) \\
\text { dy } / \mathrm{dx}\end{array}$ \\
\hline Probability & 0.053 & 0.084 & 0.738 & 0.079 & 0.045 \\
\hline Fruit color & $0.170^{* * * z}$ & $0.105 * * *$ & $-0.155^{* *}$ & $-0.071 * * *$ & $-0.049 * * *$ \\
\hline Fruit uniformity & $0.190 * * *$ & $0.112 * * *$ & $-0.177 * *$ & $-0.074 * * *$ & $-0.051 * * *$ \\
\hline Soluble solids & $0.238^{* * *}$ & $0.124 * * *$ & $0.227 * * *$ & $-0.081 * * *$ & $-0.054 * * *$ \\
\hline Pit removal & $-3.014 * *$ & $-3.084 * * *$ & $0.368^{* *}$ & $3.119 * * *$ & $2.610^{* * *}$ \\
\hline Other & 0.027 & 0.025 & -0.012 & -0.022 & -0.018 \\
\hline Disease resistance & Base & Base & Base & Base & Base \\
\hline $\begin{array}{l}\text { Disease resistance } * \\
\quad \text { years of experience }\end{array}$ & $-0.017 * *$ & $-0.018 * *$ & 0.002 & $0.017 * *$ & $0.015^{* *}$ \\
\hline Pit removal $*$ acreage & -3.026 & -3.096 & 0.370 & 3.131 & 2.620 \\
\hline
\end{tabular}

2*,**,*** Significant at $P \leq 0.100,0.050$, or 0.010 , respectively.

Table 4. Pairwise $t$ test comparisons of the importance of selected tart cherry fruit quality and tree traits based on audience survey results from one producer meeting in $2011(\mathrm{n}=55)$.

\begin{tabular}{|c|c|c|c|c|c|c|c|c|}
\hline & Fruit color & Fruit firmness & Fruit uniformity & Soluble solids & Pit removal & Machine harvest ability & Productivity & Other \\
\hline Fruit color & - & $-1.555^{* * * z}$ & 0.072 & 0.233 & 0.029 & $-0.581^{* *}$ & $-1.687 * * *$ & $-0.697 * * *$ \\
\hline Fruit firmness & & - & $1.627 * * *$ & $1.788 * * *$ & $1.584 * * *$ & $0.974 * * *$ & -0.132 & $0.858 * * *$ \\
\hline Fruit uniformity & & & - & 0.160 & -0.043 & $-0.653 * * *$ & $-1.760 * * *$ & $-0.770 * * *$ \\
\hline Soluble solids & & & & - & -0.204 & $-0.814 * * *$ & $-1.919 * * *$ & $-0.930 * * *$ \\
\hline Pit removal & & & & & - & $-0.610 * *$ & $-1.716 * * *$ & $-0.726^{* * *}$ \\
\hline Machine harvest ability & & & & & & - & $-1.106 * * *$ & -0.117 \\
\hline Productivity & & & & & & & - & $0.989 * *$ \\
\hline Other & & & & & & & & - \\
\hline
\end{tabular}

z*, **, *** Significant at $P \leq 0.100,0.050$, or 0.010 , respectively. 
most important trait when compared with participants from smaller orchards.

The sweet cherry $t$ test results are listed in Table 7. Fruit size and fruit flavor are

significantly different from all of the other traits except each other. Fruit firmness is significantly different from all of the other traits. Additionally, "other traits" is significantly

Table 5. Estimated ordered probit model coefficients indicating the relative importance of sweet cherry fruit quality and plant traits to sweet cherry producers based on an audience survey collected at a producer meeting in $2011(\mathrm{n}=87)$.

\begin{tabular}{|c|c|c|c|}
\hline Variable & Coefficient $^{\mathrm{z}}$ & SE & $P$ value \\
\hline Fruit size & $2.197 * * *$ & 0.233 & 0.000 \\
\hline Fruit skin color & 0.136 & 0.216 & 0.527 \\
\hline Fruit flavor & $2.086 * * *$ & 0.244 & 0.000 \\
\hline Fruit firmness & $1.574 * * *$ & 0.229 & 0.000 \\
\hline Freedom from pitting & $0.522 * *$ & 0.225 & 0.020 \\
\hline Extended harvest season & -0.182 & 0.273 & 0.504 \\
\hline Self-fertility & -0.020 & 0.213 & 0.925 \\
\hline Powdery mildew resistance & $0.446^{* *}$ & 0.221 & 0.043 \\
\hline Other & $0.848 * * *$ & 0.231 & 0.000 \\
\hline Viral disease resistance & Base & Base & Base \\
\hline $\begin{array}{l}\text { Extended harvest season * years } \\
\text { of experience }{ }^{\mathrm{y}, \mathrm{x}}\end{array}$ & -0.111 & 0.069 & 0.106 \\
\hline Fruit flavor $*$ acreage $^{\mathrm{w}}$ & $-0.119 * *$ & 0.052 & 0.021 \\
\hline Cutoff value $1^{\mathrm{v}}$ & -0.973 & 0.163 & \\
\hline Cutoff value $2^{v}$ & -0.432 & 0.157 & \\
\hline Cutoff value $3^{v}$ & 1.976 & 0.183 & \\
\hline Cutoff value $4^{\mathrm{v}}$ & 2.573 & 0.194 & \\
\hline Number of observations & 600 & & \\
\hline Log likelihood & -580.830 & & \\
\hline Pseudo $R^{2}$ & 0.181 & & \\
\hline
\end{tabular}

z*,**,*** Significant at $P \leq 0.100,0.050$, or 0.010 , respectively.

${ }^{\mathrm{y}}$ Only significant sociodemographic and interaction terms are presented. The acreage used in the estimation is the midpoint of each acreage category. The years of experience used in the estimation is the midpoint of each years of experience category.

${ }^{\mathrm{x}}$ Interaction between fruit trait and years of decision-making experience. The Interaction is standardized with mean zero and SD of one.

winteraction between fruit trait and size (in acres) of orchard. The interaction is standardized with mean zero and SD of one.

${ }^{\mathrm{v}}$ Cutoff value for the ordered probit model. different from all of the specified traits except freedom from pitting. Freedom from pitting is significantly different from all traits except other and powdery mildew resistance. Furthermore, powdery mildew resistance differs significantly from all traits except other and fruit skin color. Fruit skin color is significantly different from fruit flavor, fruit firmness, freedom from pitting, and other. Self-fertility is significantly different from all traits except fruit skin color and extended harvest season. Extended harvest season is significantly different from all traits except fruit color and self-fertility.

\section{Discussion}

Audience surveys were used to investigate the relative importance of fruit traits and tree traits to cherry producers. Hall et al. (2005) showed that audience survey technologies encourage audience participation and engagement. Furthermore, audience survey technologies provide several key benefits, including: the ability to survey larger groups at a single point in time, elimination of data entry errors, ease of use, and decreased time when compared with pen and paper survey methods (Powe et al., 2009). Although audience survey technology has been shown to be a viable research method (McCarter and Caza, 2009), one concern is the potential impact of the audience knowing other participants' answers to a question on answers to subsequent questions. This is similar to quantifying focus group responses. We argue that

Table 6. Estimated marginal effect of relative importance of sweet cherry traits based on audience survey data collected at a sweet cherry producer meeting in $2011(\mathrm{n}=87)$

\begin{tabular}{|c|c|c|c|c|c|}
\hline & $\begin{array}{l}\text { Least important } \\
\text { trait }(\text { ranking }=1)\end{array}$ & $\begin{array}{l}\text { Second least important } \\
\text { trait (ranking }=2)\end{array}$ & $\begin{array}{l}\text { Not selected } \\
(\text { ranking }=3)\end{array}$ & $\begin{array}{l}\text { Second most important } \\
\text { trait (ranking }=4 \text { ) }\end{array}$ & $\begin{array}{l}\text { Most important trai } \\
(\text { ranking }=5)\end{array}$ \\
\hline & $\mathrm{dy} / \mathrm{dx}$ & $\mathrm{dy} / \mathrm{dx}$ & $\mathrm{dy} / \mathrm{dx}$ & $\mathrm{dy} / \mathrm{dx}$ & $\mathrm{dy} / \mathrm{dx}$ \\
\hline Probability & 0.042 & 0.075 & 0.771 & 0.077 & 0.035 \\
\hline Fruit size & $-0.065 * * * \mathrm{z}$ & $-0.100 * * *$ & $-0.536 * * *$ & $0.157 * * *$ & $0.544 * * *$ \\
\hline Fruit skin color & -0.011 & -0.014 & -0.003 & 0.016 & 0.012 \\
\hline Fruit flavor & $1.290 * * *$ & $1.534 * * *$ & $-0.601 * * *$ & $-1.558 * * *$ & $-0.666 * * *$ \\
\hline Fruit firmness & $-0.057 * * *$ & $-0.089 * * *$ & $-0.348 * * *$ & $0.173 * * *$ & $0.321 * * *$ \\
\hline Freedom from pitting & $-0.033 * * *$ & $-0.046 * * *$ & -0.046 & $0.067 * *$ & $0.058 *$ \\
\hline Extended harvest season & 0.123 & 0.146 & -0.015 & -0.224 & -0.102 \\
\hline Self-fertility & 0.002 & 0.002 & -0.000 & -0.002 & -0.002 \\
\hline Powdery mildew resistance & $-0.029 * * *$ & $-0.041 * *$ & -0.034 & $0.057 *$ & 0.047 \\
\hline Other & $-0.043 * * *$ & $-0.066 * * *$ & $-0.119^{*}$ & $0.111 * * *$ & $0.118 * *$ \\
\hline Viral disease resistance & Base & Base & Base & Base & Base \\
\hline $\begin{array}{l}\text { Extended harvest season } * \\
\text { years of experience }\end{array}$ & 0.010 & 0.012 & -0.001 & -0.013 & -0.009 \\
\hline Fruit flavor $*$ acreage & $0.011 * *$ & 0.013 & -0.001 & $-0.013 * *$ & $-0.009 * *$ \\
\hline
\end{tabular}

z*,**,*** Significant at $P \leq 0.100,0.050$, or 0.010 , respectively.

Table 7. Pairwise $t$ test comparisons of the importance of selected sweet cherry fruit quality and plant traits collected at a sweet cherry producer meeting in 2011 $(\mathrm{n}=87)$.

\begin{tabular}{|c|c|c|c|c|c|c|c|c|c|}
\hline & Fruit size & $\begin{array}{l}\text { Fruit skin } \\
\text { color }\end{array}$ & $\begin{array}{l}\text { Fruit } \\
\text { flavor }\end{array}$ & $\begin{array}{c}\text { Fruit } \\
\text { firmness }\end{array}$ & $\begin{array}{c}\text { Freedom } \\
\text { from pitting }\end{array}$ & $\begin{array}{c}\text { Extended } \\
\text { harvest season }\end{array}$ & Self-fertility & $\begin{array}{l}\text { Powdery mildew } \\
\text { resistance }\end{array}$ & Other \\
\hline Fruit size & - & $2.061 * * * z$ & 0.111 & $0.624 * * *$ & $1.675 * * *$ & $2.380 * * *$ & $2.218 * * *$ & $1.751 * * *$ & $1.349 * * *$ \\
\hline Fruit skin color & & - & $-1.950 * * *$ & $-1.437 * * *$ & $-0.386^{*}$ & 0.319 & 0.146 & -0.310 & $-0.712 * * *$ \\
\hline Fruit flavor & & & - & $0.512 * *$ & $1.564 * * *$ & $2.269 * * *$ & $2.106 * * *$ & $1.640 * * *$ & $1.238 * * *$ \\
\hline Fruit firmness & & & & - & $1.052 * * *$ & $1.757 * * *$ & $1.594 * * *$ & $1.128 * * *$ & $0.726 * * *$ \\
\hline Freedom from pitting & & & & & - & $0.705 * *$ & $0.542 * *$ & 0.076 & -0.326 \\
\hline Extended harvest season & & & & & & - & -0.162 & $-0.629 * *$ & $-1.031 * * *$ \\
\hline Self-fertility & & & & & & & - & $-0.466 * *$ & $-0.868 * * *$ \\
\hline Powdery mildew resistance & & & & & & & & - & $-0.402 *$ \\
\hline Other & & & & & & & & & - \\
\hline
\end{tabular}

z*,**,*** Significant at $P \leq 0.100,0.050$, or 0.010 , respectively. 
cherry producers' valuation of different traits is often influenced by external information, including information from their fellow producers. Furthermore, many decisions are made after obtaining information from several sources. Therefore, in this instance, any potential group effect strengthens the methodology because it is more representative of a real world decision-making process.

Audience participants were shown introductory materials about the benefits of using marker-assisted technology in breeding and were given an update on breeding programs before the formal audience survey. This introduction highlighted the importance of participants' feedback as a means of guiding future breeding program efforts and got the participants thinking about trait options before being asked questions about the traits' level of importance. Providing trait definitions in advance helped ensure that participants had similar understandings of what a trait actually referred to.

Ordered probit models were used to analyze the audience survey data. This method of ordering responses has been used successfully in prior research to determine the importance of product attributes (Davis and Gillespie, 2004; Greene and Hensher, 2008). The producers' rankings of the traits depend on an underlying utility/satisfaction derived from the different traits. Lancaster's theory of consumer behavior states that consumer behavior is not derived from a good itself (such as the cherry fruit or tree traits) but rather from the benefits the consumer (in this instance the cherry producer) obtains from that good (Lancaster, 1966). In this research, the cherry producers know which traits provide them with the most utility but the researcher does not. Here, utility represents the value of all the elements that cherry producers consider when ranking the quality traits according to their individual preferences. Ultimately, this study provides a measurement of cherry producers' preferences derived from the rankings of cherry fruit and tree traits.

To successfully anticipate demand and provide the marketplace with desirable and innovative cultivars for the fresh or processing market, breeders should understand the trait priorities for all relevant supply chain parties including producers, marketing intermediaries, and consumers. This study focuses specifically on producers' trait prioritization and it is a part of a large project funded by U.S. Department of Agriculture "RosBREED: Enabling Marker Assisted Breeding." In the larger project, we have conducted studies that focus on trait prioritization of other industry stakeholders such as marketing intermediaries and consumers. Synthesizing the trait priority information from all the supply chain members will ultimately be of great value to inform breeders in their planning of crosses, relative allocation of resources for phenotypic or genotypic selection among experimental lines, and commercialization decisions.

In the United States, $\approx 20$ sweet cherry cultivars are grown for the fresh market
(Brown et al., 1996; Long et al., 2007); however, for tart cherry, one cultivar constitutes $\approx 99 \%$ of the U.S. production. Tart cherry crop losses resulting from freeze damage in 2002 have been devastating as a result of the nearly exclusive production of this one cultivar, Montmorency (Iezzoni, 2005). Consequently, in addition to the traits evaluated in this study, breeders are also developing new cultivars having a later bloom time than the exclusive cultivar to reduce the probability of catastrophic crop loss (Iezzoni, 2005).

\section{Conclusion}

Overall, cherry fruit producers value specific fruit and tree traits differently depending on the types of fruits they produce and their demographic differences. Producers have slightly different needs based on their demographics. For instance, the most important traits to tart cherry producers are productivity and fruit firmness. Interestingly, disease resistance becomes more important for tart cherry producers who have more years of experience. The most important traits to sweet cherry producers are fruit size, fruit flavor, fruit firmness, other, freedom from pitting, and powdery mildew resistance. Fruit flavor became less important to sweet cherry producers as their orchard size (in terms of acres) increased.

In conclusion, a core objective of the RosBREED project is to quantify the value that supply chain member groups place on different cherry fruit quality and tree traits and incorporate that information into the cherry breeders' decisions as they plan their breeding programs. In this study we focus on cherry producers. The current study summarizes the important traits for tart cherry and sweet cherry producers. Cherry breeders can use the information to increase efficiency in their breeding programs by targeting important traits. The breeder's risk in developing and commercializing new cherry cultivars may also be reduced as a result of the increased likelihood of market acceptance and marketability of new cultivars. New cultivars with high and rapid adoption may benefit all members of the supply chain as well as consumers. Additionally, our results add to the literature on sweet and tart cherry traits and supply chain research, quantify cherry producers' trait prioritization, and provide valuable insights that have potential to increase industry growth and profitability through the coordination of supply chain members' needs in new cherry cultivars.

\section{Literature Cited}

Alpuerto, V.E., G.W. Norton, J. Alwang, and A.M. Ismail. 2009. Economic impact analysis of marker-assisted breeding for tolerance to salinity and phosphorous deficiency in rice. Rev. Agr. Econ. 31:779-792.

Brown, S.K., A.F. Iezzoni, and H.W. Fogle. 1996. Cherries, p. 213-225. In: Janick, J. and J.N. Moore (eds.). Fruit breeding, tree and tropical fruits. John Wiley and Sons, Inc., New York, NY.

Census of Agriculture. 2007. Fruits and nuts: 2007 and 2002. 16 Apr. 2014. <http://www.agcensus. usda.gov/Publications/2007/Full_Report/Volume_ 1,_Chapter_2_US_State_Level/st99_2_032_032. pdf $>$.

Davis, C.G. and J.M. Gillespie. 2004. What role does specialization play in farm size in the U.S. Hog Industry? Southern Agr. Econ. Assn. Annu. Mtg., Tulsa, OK.

Dever, M.X., R.A. MacDonald, M.A. Cliff, and W.D. Lane. 1996. Sensory evaluation of sweet cherry cultivars. HortScience 31:150-153.

Fuglie, K.O. and T.S. Walker. 2001. Economic incentives and resource allocation in U.S. public and private plant breeding. J. Agr. Appl. Econ. 33:459-473.

Greene, W.H. and D.A. Hensher. 2008. Modeling ordered choices: A primer and recent developments. New York University, New York, NY.

Hall, R.H., H.L. Collier, M.L. Thomas, and M.G. Hilgers. 2005. A student response system for increasing engagement, motivation, and learning in high enrollment lectures. Proc. $11^{\text {th }}$ Amer. Conf. Info. Syst. p. 1-7.

Hennessy, D.A., J.A. Miranowski, and B.A Babcock. 2004. Genetic information in agricultural productivity and product development. Amer. J. Agr. Econ. 86:73-87.

Iezzoni, A.F. 2005. Acquiring cherry germplasm from central and eastern Europe. HortScience 40:304-308.

Kappel, F., B. Fisher-Fleming, and E. Hogue. 1996. Fruit characteristics and sensory attributes of an ideal sweet cherry. HortScience 31:443-446.

Knopf, D. 2011. U.S. peach production down 2 percent from 2010 apricots down 9 percent from last year. Natl. Agr. Stat. Serv., USDA. 29 May 2012. <http://www.nass.usda.gov/Statistics_by_ State/Washington/Publications/Current_News_ Release/peaches.pdf>.

Lancaster, K.J. 1966. A new approach to consumer behavior theory. J. Polit. Econ. 74:132-157.

Long, L.E., M. Whiting, and R. Nunez-Elisea. 2007. Sweet cherry cultivars for the fresh market. Pacific Northwest Extension Publication \#604.

Luby, J. and D. Shaw. 2001. Does marker-assisted selection make dollars and sense in a fruit breeding program? HortScience 36:872-879.

Lusk, J.L. 2007. Economic value of selecting and marketing cattle by leptin genotype. J. of Agr. and Res. Econ. 32:306-329.

McCarter, M.W. and A. Caza. 2009. Audience response systems as a data collection method in organizational research. J. Mgt. Organ. 15:122-131.

NASS. 2013. National statistics for cherries. 9 Aug. 2013. <http://www.nass.usda.gov/Statistics by_Subject/result.php?7AAB523A-4D04-3B6AA0C0-8F5F960F94D3\&sector $=$ CROPS\&group= FRUIT\%20\%26\%20TREE\%20NUTS\&comm= CHERRIES $>$

Powe, B.D., R.C. Faulkenberry, L. Harmond, and D.L. Cooper. 2009. Evaluating the use of an audience response technology system to collect research data among African American elders. Ageing Intl. 34:60-66.

Song, G.Q., G.A. Lang, K.C. Sink, and S.V. Dolgov. 2008. Cherries, p. 161-188. In: Kole C. and T.C. Hall (eds.). A compendium of transgenic crop plants. Wiley- Blackwell, Hoboken, NJ.

Stehr, R. 2001. Screening of sweet cherry cultivars in northern Germany. ISHS Acta Horticulturae 667: IV International Cherry Symposium.

Sy, H.A., M.D. Faminow, G.V. Johnson, and G. Crow. 1997. Estimating the values of cattle characteristics using and ordered probit model. Amer. J. Agr. Econ. 79:463-476. 
Tamm, L., A. Häseli, J.G. Fuchs, F.P. Weibel, and E. Wyss. 2002. Organic fruit production in humid climates of Europe: Bottlenecks and new approaches in disease and pest control. Proc. XXVI Intl. Hort. Congr.: Sust. of Hort. Syst. in the 21st Century 638:333-339.

Tano, K., M. Kamuanga, M.D. Faminow, and B. Swallow. 2003. Using conjoint analysis to estimate farmer's preferences for cattle traits in West Africa. Ecol. Econ. 45:393-407.

Timm, E.J. and D.E. Guyer. 1998. Tart cherry firmness and quality changes during mechanical harvesting and handling. Appl. Eng. in Agr. 14:153-158.

USDA. 2011. Tart cherry production up 40 percent. NASS, USDA. 29 May 2012. <http://usda01.
library.cornell.edu/usda/nass/CherProd/2010s/ 2011/CherProd-06-23-2011.pdf>.

Wearing, C.H., J.D. Hansen, C. Whyte, C.E. Miller, and J. Brown. 2001. The potential for spread of codling moth (Lepidoptera tortricidae) via commercial sweet cherry fruit: A critical review and risk assessment. Crop Prot. 20:465-488. 